\title{
Hepatitis C in hemodialysis: the contribution of injection drug use
}

\section{Authors}

Bruno Galperim ${ }^{1,2}$

Angelo A Mattos ${ }^{2}$

Airton T Stein ${ }^{3}$

Nuttiane C Schneider ${ }^{1}$

André Buriol $^{4}$

André Fonseca ${ }^{4}$

Vagner Lunge ${ }^{4}$

Nilo Ikuta $^{4}$

${ }^{1}$ Gastroenterology Service, Hospital Mãe de Deus and Hospital Nossa Senhora da Conceição, Porto Alegre, RS, Brazil.

${ }^{2}$ Graduate Program in

Hepatology, Universidade

Federal de Ciências da

Saúde de Porto Alegre

(UFCSPA), Porto Alegre,

RS, Brazil.

${ }^{3}$ Teaching and Research

Management, Grupo

Hospitalar Conceição,

Porto Alegre, RS, Brazil.

Department of Collective

Health, UFCSPA and

Universidade Luterana do

Brasil (ULBRA), Canoas,

RS, Brazil.

${ }^{4}$ Simbios Laboratório,

ULBRA, Porto Alegre, RS,

Brazil.

\begin{abstract}
Background: Hepatitis C virus (HCV) infection is the most common cause of acute or chronic hepatitis in patients on hemodialysis (HD). The purpose of this study was to describe the prevalence of positive HCV RNA and investigate injection drug use as an emerging risk factor in patients with chronic renal disease on HD. Methods: This was a multicenter cross-sectional study with 325 patients with chronic renal disease on HD in the period between August 1, 2005 to August 30, 2006, receiving care at four institutions in the city of Porto Alegre, Southern Brazil. Epidemiological data were collected by means of a structured questionnaire. The following laboratory tests were performed: alanine aminotransferase (ALT), anti-hepatitis C virus antibodies (anti-HCV), and qualitative polymerase chain reaction (PCR). Results: Of 325 patients, 68 had positive HCV RNA results. The comparison between patients with positive and negative PCR results revealed significant differences in duration of $\mathrm{HD}$ ( mean $=71$ versus 52.4 months; $\mathrm{p}=0.02$ ); previous blood transfusion ( $92 \%$ versus $72 \%$; $<<0.01$ ); injection drug use $(13 \%$ versus $0.7 \%$; $p<$ $0.01)$; anti-HCV positivity at start of HD therapy $(60 \%$ versus $4 \%$; $<<0.01)$; and mean ALT value (39 versus $26.5 ; \mathrm{p}<0.01$ ). Logistic regression analysis showed a positive HCV RNA independently associated to being on HD for more than five years [OR: 2.1 (95\% CI $1.2-3.8)$ ]; previous blood transfusion [OR: 3.7 (95\% CI 1.4 - 9.5)]; and injection drug use [OR: 22.6 (95\% CI 4.2 - 119.6)]. Conclusion: Injection drug use was an independent risk factor for HCV infection among chronic renal disease patients on HD.
\end{abstract}

Keywords: hepatitis C virus, hemodialysis, injection drug use, risk factors.

[Braz J Infect Dis 2010;14(4):422-426]@Elsevier Editora Ltda.

\section{INTRODUCTION}

Hepatitis C virus (HCV) infection is the most common cause of acute or chronic hepatitis in patients on hemodialysis (HD). The worldwide prevalence of $\mathrm{HCV}$ viral markers among HD patients has been reported to range from 2.6\% to $54 \% \cdot{ }^{1-5}$ However, studies conducted in Brazil have revealed an increased prevalence of $\mathrm{HCV}$ viral markers among these patients, with rates ranging from $5.3 \%$ to $90.4 \% .^{6-17}$

Parenteral exposure is an effective means of HCV transmission in individuals who share needles and syringes, receive blood or blood product transfusions, or have catheters inserted for long-term vascular access, particularly in the hospital setting. ${ }^{3,18}$

Over decades, blood and blood product transfusion, volume transfused and dura- tion of HD have been considered as the main risk factors for $\mathrm{HCV}$ infection in patients undergoing HD for longer than six months. ${ }^{3,19}$ However, the risk from these sources seems to have lessened, ${ }^{20}$ since blood and blood product transfusion have become safer due to improved donor screening and reduced need for transfusion. In this context, the association between injection drug use and HCV infection, which has already been established in the general population and among drug addicts, arises as a possible risk factor for HCV infection in HD patients. . $21-34^{2}$

The objective of this study was to describe the prevalence of positive HCV RNA and investigate injection drug use as an emerging risk factor in chronic renal disease patients on hemodialysis. 


\section{SUBJECTS AND METHODS}

This was multicenter cross-sectional study with 325 patients with chronic renal disease on HD in the period between August 1, 2005 to August 30, 2006, receiving care at four institutions in the city of Porto Alegre, Southern Brazil. To be eligible, they had to be on hemodialysis for longer than six months, aged 18 years or more, agree to participate in the study, and have cognitive capacity to answer a questionnaire.

Using a structured questionnaire, previously trained interviewers, blind to laboratory results, the following information was collected from the patients: age, sex, duration of $\mathrm{HD}$, previous blood and/or blood product transfusions, and injection drug use. Creatinine levels and anti-HCV results at the onset of HD therapy were obtained from the patient records.

All study participants signed an informed consent term. This study was approved by the Research Ethics Committees of all participating institutions.

\section{Laboratory tests}

Blood samples were collected immediately before the HD session. The following tests were performed in all patients: alanine aminotransferase (ALT; dry-chemistry method; Johnson \& Johnson); anti-HCV antibodies (anti-HCV, third-generation enhanced chemiluminescence immunoassay; Johnson \& Johnson, Amersham, Bucks, UK); and detection of HCV RNA by polymerase chain reaction (PCR; in-house method with $200 \mathrm{IU} / \mathrm{mL}$ detection limit).

\section{Statistical analysis}

Descriptive statistics were used for univariate analysis. Stratified analyses were performed, when necessary, to obtain odds ratios (OR) and 95\% confidence intervals (95\% CI) using the Mantel-Haenszel chi-square test. Variables significantly associated to HCV infection at the univariate analyses where included in the multiple logistic regression analysis. The level of statistical significance was set at $\mathrm{p}<0.05$.

\section{RESULTS}

\section{Patient characteristics}

The sample comprised 325 patients ( $58.2 \%$ males) with a mean age of $54.4 \pm 15$ years (ranging from 22 to 90 years). Mean creatinine level was $9.6 \pm 3.2 \mathrm{mg} / \mathrm{dL}$. High ALT levels were observed in $12(3.7 \%)$ patients. There were 107 (32.9\%) patients anti-HCV positive and one $(0.3 \%)$ patient had an undetermined anti-HCV result (negative HCV RNA, with no history of intravenous drug use). HCV RNA was positive in 68 patients ( $21 \%$ of total sample; $63.5 \%$ of antiHCV positive patients). Thirty-one percent of the patients had been on HD for longer than five years, 76\% had previously undergone blood or blood product transfusions, and $11(3.4 \%)$ reported using injection drugs.

\section{Comparison between PCR-positive and PCR-nega- tive patients}

Patients who reported use of injection drugs were significantly more likely to have positive HCV RNA results (OR = 19.4; 95\%CI 3.7 - 135.9) (Table 1).

Table 1. Comparison of HCV RNA-positive and negative chronic renal patients on hemodialysis

\begin{tabular}{|lccccc|}
\hline Variable n (\%) & $\begin{array}{c}\text { Positive } \\
\text { HCV RNA }\end{array}$ & $\begin{array}{c}\text { Negative } \\
\text { HCV RNA }\end{array}$ & OR (95\% CI) & $\begin{array}{c}\text { p-value } \\
\text { No. of patients }\end{array}$ & $\begin{array}{c}\text { OR (95\% CI) } \\
\text { adjusted }\end{array}$ \\
\hline Male sex & $41(21)$ & $257(79)$ & - & - & - \\
\hline Age, mean \pm SD & $53.2 \pm 14.2$ & $54.6 \pm 14.8$ & - & 0.46 & $1.2(0.6$ to 2.1) \\
\hline $\begin{array}{l}\text { Time on hemodialysis* } \\
\text { (months) mean } \pm \text { SD }\end{array}$ & $71 \pm 65$ & $52.4 \pm 54.6$ & - & 0.02 & $2.1(1.2$ to 3.8) \\
\hline Blood transfusion & $60(92)$ & $187(72)$ & $3.9(1.5$ to 10.5$)$ & $<0.01$ & $3.7(1.4$ to 9.5) \\
\hline Injection drug use & $9(13)$ & $2(0.7)$ & $19.4(3.7$ to 135.9$)$ & $<0.01$ & $22.6(4.2$ to 119.6$)$ \\
\hline $\begin{array}{l}\text { Anti-HCV positive at } \\
\text { start of hemodialysis }\end{array}$ & $33 / 55(60)$ & $10 / 247(4)$ & $35.5(14.5$ to 89.6$)$ & $<0.01$ & - \\
\hline ALT (U/l), mean \pm SD & $39.8 \pm 18.9$ & $26.5 \pm 25.5$ & - & $<0.01$ & - \\
\hline
\end{tabular}

ALT, alanine aminotransferase; CI, confidence interval; HCV, Hepatitis C virus; OR, odds ratio; PCR, polymerase chain reaction; SD, standard deviation.

*For adjusted OR, time on hemodialysis $>5$ years. 
Multiple logistic regression showed that being on HD for more than five years $(\mathrm{OR}=2.1 ; 95 \% \mathrm{CI} 1.2-3.8)$, previous blood transfusion $(\mathrm{OR}=3.7 ; 95 \% \mathrm{CI} 1.4-9.5)$, and history of injection drug use $(\mathrm{OR}=22.6 ; 95 \% \mathrm{CI} 4.2$ - 119.6) were independent risk factors for positive HCV RNA result (Table 1).

\section{DISCUSSION}

The prevalence of anti-HCV antibodies varies greatly among patients on HD. ${ }^{1-15}$ In this study, 32.9\% of the patients were anti-HCV positive, which is close to that described by other authors in studies carried out in the same geographical region, ${ }^{12,14-17}$ but higher than the mean prevalence of $15.4 \%$ reported in a Brazilian national census. ${ }^{6}$ Mean anti-HCV prevalence is below $10 \%$ in developed countries, ${ }^{1,3,35}$ and the increased prevalence rate observed in our study may reflect the poor-quality care provided to this population.

In the present study, $21 \%$ of all patients and $63.5 \%$ of the anti-HCV positive patients had positive HCV RNA results. These results are similar to those reported in European studies, ${ }^{36,37}$ but lower than those found in the United States. ${ }^{31,38}$ In comparison to other Brazilian studies, although our rates are consistent with findings from some studies, ${ }^{8,12}$ our results were lower than those reported by several other studies (PCR positivity between 69\% and $100 \%$ in anti-HCV positive patients)..$^{7,9,10,16,39,40}$ This may be partially explained by the fact that the PCR technique employed in the present study had a detection limit of 200 $\mathrm{IU} / \mathrm{mL}$, which is less sensitive in HD patients, who often present low or variable viral loads.

Sex and age were not independently associated with $\mathrm{HCV}$ infection, which is consistent with the existing literature. ${ }^{39,41,42}$

Duration on HD has been described as the main independent risk factor for $\mathrm{HCV}$ infection, ${ }^{2,3,21,35,43-45}$ and each additional year on HD represents an increase of $10 \%$ to $13 \%$ in the risk of infection. ${ }^{5,46}$ In this study being on HD longer than five years was an independent risk factor for infection, which is in agreement with findings reported in other studies. ${ }^{8,10,14,37,47-50}$

The introduction of erythropoietin and iron supplementation in the management of anemia in patients with chronic renal disease has dramatically reduced the need for blood and blood product transfusions in this population. Similarly, the improvement in donor selection and the introduction of screening tests have reduced the risks of HCV infection associated with transfusion. ${ }^{2,19,21,51}$ Therefore, the current risk rates for $\mathrm{HCV}$ infection in patients on HD may differ substantially from those reported 10 or 15 years ago. ${ }^{20}$

In this study, previous blood transfusion was an independent risk factor for $\mathrm{HCV}$ infection, according to the literature. ${ }^{48,49}$ Although some studies found a signifi- cant association between blood transfusion and HCV in univariate analyses, this association was not sustained in multivariate models. ${ }^{37,46,47}$ Likewise, similar findings were reported in Brazilian studies. , $^{8,13,14,39,42,50}$

Some patients had HCV infection markers before they were started on hemodialysis therapy, which is a potentially undefined risk factor. In this study, 14.2\% (76\% with positive HCV RNA) of all patients were anti-HCV positive before starting HD therapy, as reported in previous studies. ${ }^{20,33}$ Sandhu et al. ${ }^{34}$ observed that HCV infection was eight times greater for patients with chronic renal disease and risk behavior.

Among the general population, injection drug use is the main risk factor for $\mathrm{HCV}$ infection and accounts for $68 \%$ of new cases. ${ }^{21}$ Some authors have classified injection drug use as an additional risk factor for $\mathrm{HCV}$ infection in patients on HD. ${ }^{2,20,32-34,46,47}$ In our study, this variable was an independent risk factor for HCV infection, with an adjusted OR of 22.6. This result is in agreement with findings reported by Sandhu et $a .^{34}$ and Bergman et al. ${ }^{20}$ who found a non-adjusted OR of 55.3 and an adjusted OR of 6.6, respectively, and by other investigators. ${ }^{2,10,32,46,47}$

Jadoul $^{35}$ considers injection drug use as a risk factor, especially in American cohorts, which is supported by data from the Centers for Disease Control and Prevention (CDC). ${ }^{44}$ This author also points out that drug use seems to be less important in European samples, as shown in studies conducted in Germany, France, and Belgium, where injection drug use was not a risk factor for $\mathrm{HCV}$ infection in patients on HD. ${ }^{37,49,52}$ No similar reports analyzing this association in Latin American patients could be retrieved in our literature review.

In the general population, ${ }^{21}$ as well as in groups of intranasal cocaine users ${ }^{53}$ and alcohol abusers, ${ }^{54}$ injection drug use has been shown to be an established risk factor for $\mathrm{HCV}$ infection. In our study, this association was clearly demonstrated in patients on HD. One possible limitation worth mentioning is that some patients in this study may not have admitted drug use, which could translate into underestimation. ${ }^{34}$

In summary, injection drug use was an important risk factor for HCV infection in this cohort of chronic renal failure patients on HD.

\section{REFERENCES}

1. Fabrizi F, Poordad FF, Martin P. Hepatitis C infection and patient with end-stage renal disease. Hepatology 2002; 36:3-10.

2. Pereira BJ, Levey AS. Hepatitis $C$ virus infection in dialysis and renal transplantation. Kidney Int 1997; 51:981-99.

3. Recommendations for preventing transmission of infections among chronic hemodialysis patients. MMWR Recomm Rep 2001; 50:1-43.

4. Sampietro M, Badalamenti S, Graziani G. Nosocomial hepatitis C in dialysis units. Nephron 1996; 74:251-60. 
5. Fissell RB, Bragg-Gresham JL, Woods JD et al. Patterns of hepatitis $\mathrm{C}$ prevalence and seroconversion in hemodialysis units from three continents: the DOPPS. Kidney Int 2004; 65:2335-42.

6. Romão Jr JE, Pinto SWL, Canziani ME et al. Brazilian Society of Nephrologys (SBN) annual survey report on epidemiology of dialysis facilities in Brazil. J Bras Nefrol 2003; 25:187-98.

7. Moreira R, Pinho JR, Fares J et al. Prospective study of hepatitis $\mathrm{C}$ virus infection in hemodialysis patients by monthly analysis of HCV RNA and antibodies. Can J Macrobiol 2003; 49:503-7.

8. Carneiro MA, Martins RM, Teles SA et al. Hepatitis C prevalence and risk factors in hemodialysis patients in central Brazil: a survey by polymerase chain reaction and serological methods. Mem Inst Oswaldo Cruz 2001; 96:765-9.

9. Busek SU, Babá EH, Tavares Filho HA et al. Hepatitis C and hepatitis $B$ virus infection in different hemodialysis units in Belo Horizonte, Minas Gerais, Brazil. Mem Inst Oswaldo Cruz 2002; 97:775-8.

10. Souza KP, Luz JA, Teles SA, Carneiro MA, Oliveira LA. Hepatitis $\mathrm{B}$ and $\mathrm{C}$ in the hemodialysis unit of Tocantins, Brazil: serological and molecular profiles. Mem Inst Oswaldo Cruz 2003; 98:599-603.

11. Gouveia EC, Lopes EPA, Moura I et al. Identification of the cutoff value for serum alanine aminotransferase in hepatitis C screening of patients with chronic renal failure on hemodialysis. Rev Soc Bras Med Trop 2004; 37:18-21.

12. Ono-Nita SK, de Moraes CR, Carrilho FJ et al. A prospective study of the prevalence of hepatitis $\mathrm{B}$ and $\mathrm{C}$ virus coinfection among patients with chronic renal disease under hemodialysis. J Hepatol 2004; 40:715-16.

13. Albuquerque AC, Coêlho MR, Lopes EP, Lemos MF, Moreira RC. Prevalence and risk factors of hepatitis $C$ virus infection in hemodialysis patients from one center in Recife, Brazil. Mem Inst Oswaldo Cruz 2005; 100:467-70.

14. Karohl C, Manfro RC, Senger MB et al. Prevalência de antivírus da hepatite $\mathrm{C}$ em pacientes em hemodiálise crônica de Porto Alegre. J Bras Nefrol 1995; 17:40-6.

15. Flores AL, Mattos AA, Goldani JC et al. Marcadores virais da hepatite em uma unidade de hemodiálise. GED 1997; 16:190.

16. Dotta MA, Chequer H, Pereira JP et al. Molecular and immunological methods in the diagnosis of hepatitis $\mathrm{C}$ virus in patients on hemodialysis. J Bras Nefrol 2003; 25:86-94.

17. Lopes CV, Karnopp T, Burmeister JE et al. Detection of hepatitis $\mathrm{C}$ by polymerase chain reaction in chronic renal patients in hemodialysis and non-reagent anti-VHC. GED 2005; 24:1-5.

18. Hörl WH. Neutrophil function and infections in uremia. Am J Kidney Dis 1999; 33:45-48.

19. Tokars JI, Alter MJ, Favero MS et al. National surveillance of dialysis associated diseases in the United States, 1992. ASAIO J 1994; 40:1020-31.

20. Bergman S, Accortt N, Turner A, Glaze J. Hepatitis C infection is acquired pre-ESRD. Am J Kidney Dis 2005; 45:684-9.

21. Alter MJ. Prevention of spread of hepatitis C. Hepatology 2002; 36:93-8.

22. van den Hoek JA, van Haastrecht HJ, Goudsmit J, de Wolf F, Coutinho RA. Prevalence, incidence, and risk factors of hepatitis $C$ virus infection among drug users in Amsterdam. J Infect Dis 1990; 162:823-6.

23. Woodfield DG, Harness M, Rix-Trott K. Hepatitis C virus infections in oral and injectable drug users. N Z Med J 1993; 106:332-4.
24. Woodfield DG, Harness M, Rix-Trott K et al. Identification and genotyping of hepatitis $\mathrm{C}$ virus in injectable and oral drug users in New Zealand. Aust N Z J Med 1994; 24:47-50.

25. Apichartpiyakul C, Chittivudikarn C, Miyajima H, Homma M, Hotta $\mathrm{H}$. Analysis of hepatitis $\mathrm{C}$ virus isolates among healthy blood donors and drug addicts in Chiang May, Thailand. J Clin Microbiol 1994; 32:2276-9.

26. Thomas DL, Vlahov D, Solomon L et al. Correlates of hepatitis $\mathrm{C}$ virus infections among injection drug users. Medicine (Baltimore) 1995 ; 74:212-20.

27. Santana Rodríguez OE, Malé Gil ML, Hernández Santana JF, Limiñana Cañal JM, Martín Sanchez AM. Prevalence of serologic markers of HBV, HDV, HCV and HIV in non-injection drug users compared to injection drug users in Gran Canaria, Spain. Eur J Epidemiol 1998; 14:555-61.

28. Smyth BP, Keenan E, O'Connor JJ. Bloodborne viral infection in Irish injecting drug users. Addiction 1998; 93:1649-56.

29. de Carvalho HB, Mesquita F, Massad E et al. HIV and infections of similar transmission patterns in a drug injectors community of Santos, Brazil. J Acquir Immune Defic Syndr Hum Retrovirol 1996; 12:84-92.

30. Oliveira ML, Bastos FI, Telles PR et al. Prevalence and risk factors for HBV, HCV and HDV infections among injecting drug users from Rio de Janeiro, Brazil. Braz J Med Biol Res 1999; 32:1107-14.

31. Treitinger A, Spada C, Silva EL et al. Prevalence of serologic markers of HBV and HCV infection in HIV-1 seropositive patients in Florianópolis, Brazil. Braz J Infect Dis 1999; 3:1-5.

32. Stehman-Breen CO, Emerson S, Gretch D, Johnson RJ. Risk of death among chronic dialysis patients infected with hepatitis $\mathrm{C}$ virus. Am J Kidney Dis 1998; 32:629-34.

33. Petrosillo N, Gilli P, Serraino D et al. Prevalence of infected patients and understaffing have a role in hepatitis $C$ virus transmission in dialysis. Am J Kidney Dis 2001; 37:1004-10.

34. Sandhu J, Preiksaitis JK, Campbell PM, Carriere KC, Hessel PA. Hepatitis $\mathrm{C}$ prevalence and risk factors in the northern Alberta dialysis population. Am J Epidemiol 1999; 150:58-66.

35. Jadoul M. Epidemiology and mechanisms of transmission of the hepatitis C virus in haemodialysis. Nephrol Dial Transplant 2000; 15:39-41.

36. Schneeberger PM, Keur I, van der Vliet W et al. Hepatitis C virus infection in dialysis centers in the Netherlands: a national survey by serological and molecular methods. J Clin Microbiol 1998; 36:1711-5.

37. Salama G, Rostaing L, Sandres K, Izopet J. Hepatitis C virus infection in French hemodialysis units: a multicenter study. J Med Virol 2000; 61:44-51.

38. Bukh J, Wantzin P, Krogsgaard K et al. High prevalence of hepatitis $\mathrm{C}$ virus (HCV) RNA in dialysis patients: failure of commercially available antibody tests to identify a significant number of patients with HCV infection. Copenhagen Dialysis HCV Study Group. J Infect Dis 1993; 168:1343-8.

39. Carvalho M, Branco PB, Luvizotto ML et al. High prevalence of hepatitis $\mathrm{C}$ virus infection in chronic hemodialysis patients. Braz J Infect Dis 1999; 3:144-8.

40. Silva LK, Silva MB, Rodart IF et al. Prevalence of hepatitis C virus (HCV) infection and $\mathrm{HCV}$ genotypes of hemodialysis patients in Salvador, Northeastern Brazil. Braz J Med Biol Res 2006; 39:595-602.

41. Kumagai J, Komiya Y, Tanaka J et al. Hepatitis C virus infection in 2,744 hemodialysis patients followed regularly at nine centers in Hiroshima during November 1999 through February 2003. J Med Virol 2005; 76:498-502. 
42. Santana GO, Cotrim HP, Mota E et al. Anticorpo contra o vírus $\mathrm{C}$ da hepatite em pacientes sob programa de hemodiálise em Salvador, BA, Brasil. Arq Gastroenterol 2001; 38:24-31.

43. Kellerman S, Alter MJ. Preventing hepatitis B and hepatitis C virus infections in end-stage renal disease patients: back to basics. Hepatology 1999; 29:291-3.

44. Moyer LA, Alter MJ. Hepatitis C virus in the hemodialysis setting: a review with recommendations for control. Semin Dial 1994; 7:124-7.

45. Le Pogam S, Le Chapois D, Christen R et al. Hepatitis C in a hemodialysis unit: molecular evidence for nosocomial transmission. J Clin Microbiol 1998; 36:3040-3.

46. Hardy NM, Sandroni S, Danielson S, Wilson WJ. Antibody to hepatitis $\mathrm{C}$ virus increases with time on hemodialysis. Clin $\mathrm{Ne}-$ phrol 1992; 38:44-8.

47. Niu MT, Coleman PJ, Alter MJ. Multicenter study of hepatitis C virus infection in chronic hemodialysis patients and hemodialysis center staff members. Am J Kidney Dis 1993; 22:568-73.

48. Alavian SM, Einollahi B, Hajarizadeh B et al. Prevalence of hepatitis $\mathrm{C}$ virus infection and related risk factors among Iranian haemodialysis patients. Nephrology (Carlton) 2003; 8:256-60.
49. Hinrichsen H, Leimenstoll G, Stegen G et al. Prevalence and risk factors of hepatitis $\mathrm{C}$ virus infection in haemodialysis patients: a multicentre study in 2796 patients. Gut 2002; 51:429-33.

50. Carneiro MA, Teles SA, Dias MA et al. Decline of hepatitis $\mathrm{C}$ infection in hemodialysis patients in Central Brazil: a ten years of surveillance. Mem Inst Oswaldo Cruz 2005; 100:345-9.

51. Gresens CJ, Holland PV. The disappearance of transfusiontransmitted hepatitis $\mathrm{C}$ virus infections in the United States. Clin Liver Dis 2001; 5:1105-13.

52. Jadoul M, Cornu C, van Ypersele de Strihou C. Incidence and risk factors for hepatitis $\mathrm{C}$ seroconversion in hemodialysis: a prospective study. The UCL Collaborative Group. Kidney Int 1993; 44:1322-6.

53. Galperim B, Cheinquer $\mathrm{H}$, Stein A et al. Intranasal cocaine use does not appear to be an independent risk factor for HCV infection. Addiction 2004;99:973-7.

54. Galperim B, Cheinquer H, Stein A et al. Prevalence of hepatitis $\mathrm{C}$ virus in alcoholic patients: role of parenteral risk factors. Arq Gastroenterol 2006; 43:81-4. 